LSP International Journal, Vol. 8, Issue 1, 2021, 57-65

(C) Universiti Teknologi Malaysia

E-ISSN 2601-002X

DOI: https://doi.org/10.11113/lspi.v8.17129

\title{
Tourism-related Coronaneologisms
}

\author{
Tina Orel Frank* \\ University of Primorska, The Faculty of Tourism Studies - Turistica, Obala 1la, \\ Portorož, Slovenia
}

Submitted: 4/6/2021. Revised edition: 21/6/2021 Accepted: 21/06/2021. Published online: 28/6/2021

\begin{abstract}
In linguistic research, there have been numerous recent attempts to extract and analyse covidneologisms, yet the field of languages for specific purposes is to the date left unresearched. Coronaneologisms are neologisms in the neologistic phase of the word life cycle at the time of the recent catastrophic COVID -19 outbreak, which was particularly devastating in the tourism sector. The paper is therefore concerned with the emergence of new tourism-related coronaneologisms. It extracts them by analysing previous academic research on the subject, by observing tourism-related sources on the Internet and by conducting interviews with academic professionals in the field of tourism at The Faculty of Tourism Studies - Turistica in Slovenia as an active tourism discourse community. The list of tourism-related coronaneologisms contributes to the understanding of current languages for specific purposes in general and examines the new lexis from the perspective of the current socio-cultural challenges tourism is facing.
\end{abstract}

Keywords: Coronaneologisms, the language for tourism purposes, COVID-19, Coronavirus

\subsection{INTRODUCTION}

Under the influence of social, cultural and historical changes, languages are constantly evolving (Stojičić, 2004; Harley, 2006; Halliday \& Yallop, 2007; Gladkova, 2015). The same mechanisms that govern social diffusion and non-linguistic innovation can thus explain language change (Maybaum 2013: 152). In the process of internal change, which can also be influenced by foreign language factors, lexis seems to be the most susceptible to change and thus one of the most important indicators of language development, reflecting the world in which it is used (Halliday and Yallop 2007; Kecskes 2015), so the social context must always be taken into account when studying new coinages (Fischer 1998: 7). In 2020, the world was hit by a global outbreak of Covid-19, which brought socio-economic challenges that appear to have long-term implications for languages as well. New expressions were formed out of the need to name new concepts and phenomena (Crystal 2003; Lehrer 2003: 371; Stojičić 2004; Gložančev 2009; Francl 2011: 417; Janssen 2013; Barrs 2015: 372), but also to keep language alive and diverse. New coinages reflect the current state of the world, which has experienced a massive disruption in the form of COVID -19 pandemics. COVID -19 pandemic has affected the

\footnotetext{
*Correspondence to: Tina Orel Frank (email: tina.orel@fts.upr.si)
} 
operations in many areas. Besides education, business, governance and many others, it has massively affected tourism. Tourism has experienced a period of foreclosure, which has also led to a massive and exponential emergence describing new vacationing practices and ways of doing business, both live and online. In a pre-Covid description of tourism Malenkina \& Ivanov (2018) define tourism as a dominant cultural industry and one of the most important economic fields of activity under the impact of globalization, which highlights the importance of linguistic commodification in terms of changing identities, interpersonal relationships, and altering community structures. However, the outbreak of COVID -19 has completely changed the tourism profile, with tourist arrivals in January 2021 falling to a record 87\% compared to 2020 (UNWTO, 2021). The latest UNWTO World Tourism Barometer (2021) reports all world regions experiencing a sharp decline in tourist arrivals. Closures or restrictions on border crossings, mandatory testing, quarantines, slowed distribution of vaccinations have hampered the resumption of international travel, which has been affected at virtually all levels of the hospitality chain, leading to reports of layoffs and bankruptcies (Gössling, Scott \& Hall 2021). The authors say that tourism is resilient and will recover, but there is much evidence that the virus will also be transformative for the tourism sector and its lexis.

The paper aims at collecting and examining tourism-related coronaneologisms. It is a rare opportunity for both lexicographers and other researchers to observe how a topic overwhelms global discourse to such an extent and in such a short time. This, combined with the fact that most global communication took place online, meaning that it is recorded and stored, makes this a unique opportunity to observe the development not only of general languages but also of languages for specific purposes, especially in a field that has been as affected as tourism. The need to fill conceptual and terminological gaps is even more urgent in times of pandemic (Haddad Haddad \& MonteroMartinez 2020). The neologisms in this study highlight the current lexical changes that the language of tourism has undergone in the ongoing COVID era. On the one hand, the new expressions serve as an important tool in observing language variation, and on the other hand, they point to the current perspectives of tourism. The current "buzzwords" or "keywords" of tourism play an important role in the "forming a special socio-cultural space" (Samylicheva \& Gazda 2020: 2) and play a vital role in the development of various possible word-formative abilities in naming resulting from the intense popularisation of objects or phenomena (Žele, 2010: 132).

\subsection{LITERATURE REVIEW}

Neologisms are usually described as newly coined words or phrases or as those that have undergone a recent semantic change (Oxford Dictionary; Collins Cobuilt Dictionary; Cambridge Advanced Learner's Dictionary; Simeon 1969: 904-905; Algeo 1991: 2; Newmark 1995; Muhvić-Dimanovski 2005). More precisely, we rather speak of a neologism as a lexeme that is at a certain point in time in a neologistic phase of the word life cycle. Thus, a new lexis is described as referring to a specific period of time, and a word thus cannot be permanently described as a neologism, as it may go out of use or become institutionalised. Due to the complexity of the relationship between old and new, the neologistic phase can only be understood according to several separate or overlapping approaches. 
First, the diachronic approach defines neologism as a lexeme that has emerged recently, is fairly well established, but has lost its status as a nonce word (Toporišič 2000: 130; Fischer 1998). Nonce words or occasionalisms represent an earlier stage in the word life cycle. Thus, some authors distinguish occasionalisms (e.g. Crystal 2008: 315) from neologisms according to the purpose of their formation, the latter being formed to fill a lexical gap for a longer period of time, and the former filling the gaps of single unique circumstances. Second, the psychological approach defines neologisms as expressions that are stylistically marked as new by members of a particular discourse community (Rey 1995; Fischer 1998; Cabre 1998; Csak 2011; Anesa 2018). Third, the lexicographic approach defines neologisms as newly coined expressions that are not yet lexicalized - that is, not yet recorded in dictionaries (Algeo 1991; Sanders 2010 in Rets 2016; Ficher 1998; Kerremans 2015). Finally, the systems approach, which defines neologisms as lexemes that exhibit both formal (morphological, graphic and phonetic) and semantic instability. Nevertheless, neologisms must be defined according to the subjective attitude of each researcher (Rey 1995; Cabré 1998). In this paper, tourism-related coronaneologisms (Bolotina (2021) calls them "COVID -neologisms") are understood as English tourism-related new expressions that are in the neologistic phase of the lexical life cycle in the coronatime span from December 2019 to June 2021. This means that they are always considered here "only" as potential expressions that have passed their nonce word development stage, are institutionalised (fairly established) but not yet lexicalized and stylistically marked as new by the tourism discourse community.

Tourism is accepted and discussed by a wide audience, from professionals to academics to the general public, which defines the language of tourism as the language of a wide language community. "Social characteristics or group orientation" (Jaworski and Pritchard 2005: 6), which can be attributed to a group of people communicating about tourism, turns out to be an important part of the treatment of sectoral discourse. A discourse community (or discursive community, according to Mikolič 2015: 18) is formed by the participation of certain groups of individuals in a certain common activity and includes, on the one hand, the creators of texts and, on the other hand, their recipients. On the one hand, the communication contributions are influenced by the established order of discourse, and on the other hand, they influence the future development of a particular discourse. Subject-conceptual field of language for tourism purposes is defined as consisting of the professional language (of those who work in tourism and those who are interested in this activity and thus become involved in the tourism profession, and the scientific language of tourism - those who are originally concerned with tourism as a discipline); the professional and scientific language transferred to tourism from other disciplines, fields and areas that constitute and contribute to tourism, i.e. from those secondarily concerned with tourism; and the general vocabulary passed down from those who travel as tourists, participate in, are interested in, and give their responses to tourism.

This study uses the below mentioned coronaneologism-related publications as a source for creating new lexis lists. It has already been observed in numerous publications that the outbreak of COVID -19 was followed by a wave of neologisms reflecting the socio-cultural struggles of the time. Katermina \& Lipiridi (2020) conclude that the neologisms of non-professional discourse in the coronavirus pandemic "fully reflected the functioning of mass consciousness in the period of catastrophic social changes" (ibid.: 48). Similarly, Mweri (2021) collects data from various sources on language use in the realities of the pandemic and uses MAK Halliday's functional theory for her 
analysis, concluding that "linguistic creativity reflects the major preoccupations of the time" (Lawson 2020). Lei, Yang \& Huang (2021) also demonstrated a strong correlation between emergent neologisms and pandemic developments and presented new data on how new words emerge, particularly in the form of substitution changes. Alyksyeyeva, Chaiuk \& Galitska (2020) also note that coronaspeak indicates a number of sociocultural changes in modern English-speaking societies, such as the medicalization of general language, the conceptualization of the pandemic as a milestone, the introduction of new categories of social groups, the development of new or the modification of old cultural practices, new communication patterns, the reconceptualization of pre-pandemic concepts, and the emergence of new types of interpersonal relationships.

Published research also deals with the word formation process in coronaneologisms. Bolotina (2021) concludes that the general morphological processes involved in the formation of new lexical items include compounding, blending and semantic derivation. Asif, Zhiyong, Iram \& Nisar (2020) find that the word formation process in coronaneologisms is mainly used in the forms of nouns, adjectives and verbs, with abbreviations and acronyms also being relatively common. Akut (2020) similarly analyses the morphological structures of neologisms during the pandemic COVID -19 and finds in a rather small corpus (5 Internet articles), however, that most neologisms are nouns, where the most frequent morphological processes are compounding, blending and affixation. A larger list of neologisms included in the analysis is presented in Al-Salman \& Haider (2021), who conclude that various word formation processes have been used, showing the creativity and vitality of the English language to respond to the current crisis situation.

Authors also engage in specific corpus neologistic analyses. Grzega (2021) criticises COVID related contributions to Wiktionary as violating the guidelines, especially with regard to neutrality, since most contributions are made by untrained lexicographers. Khalfan, Batool and Shehzad (2020) observe 25 new words collected from dictionaries and Twitter from the point of view of linguistic relativism and were able to demonstrate the influence of language on thought and perception. AlAzzawi \& Ali-Haleem (2021) observed the database of 5 million tweets, concluding that the recent lexical changes "functioned as a tool of coping with the major changes that happened to people's lifestyles globally" (ibid.: 113).

There are some publications dealing with cross-linguistic relations. Haddad Haddad \& MonteroMartinez (2020) provide an insight into metaphor-based neologisms and their translation into Arabic and conclude that "the meronymic term coronavirus is extended worldwide, which provoke confusion and misunderstandings by laypeople" (ibid.: 18) and suggest the use of the precise neologism 'COVID 19' coined by WHO to effectively disseminate the relevant information. Samylicheva \& Gazda (2020) observe derivative neologisms as socio-cultural dominants in Russian and Checz languages again proving that "neologisms in which the inner form appears in the most naked form are also and indicator and exponent of certain values in society" (ibid.: 2). 


\subsection{METHOD}

The object of the present study is the tourism-related coronaneologisms. The coronaneologisms studied were considered in the broadest framework of the application of the neologism theory, namely those created out of denominative or creative needs, those that represent new coinages, as well as semantic shifts, reactualizations and expressions that gain frequency. The list was compiled using a twofold method. First, they were collected from previous surveys on coronaneologism (academic papers mentioned in the literature review) and from tourism-related sources on the Internet (journals, dictionaries, blogs, etc.) in the period from April 2021 to May 2021. Secondly, a group of academic researchers in the field of tourism (University of Primorska, The Faculty of Tourism Studies Turistica) contributed as an example of the tourism discourse community with their examples as well as socio-cultural views on the current tourism-related new lexis in an online Delfi method during the same period. The reason for this twofold methodology lies in the fact that the language for tourism purposes includes both professional, academic and general levels.

\subsection{RESULTS AND DISCUSSION}

This part is devoted to the presentation of the results. A total of 286 coronaneologisms were collected during the investigation. The thematic breakdown revealed (Table 1) that there were 36 directly related to tourism or therefore coined primarily for tourism purposes, 47 cases were indirectly related to tourism, and 203 were expressions that arose from other denominative or stylistic needs to fill lexical gaps. Numerical consideration of the topic implies that nearly one-third $(28 \%)$ of the new expressions were coined either to fill a direct (12\%) or indirect (16\%) tourism-related gap, demonstrating the importance of tourism discussions in the global community in times of COVID -19 pandemics.

Table 1 Coronaneologisms and their connection to tourism

\begin{tabular}{|c|c|c|}
\hline Direct connection & Indirect connection & Other \\
\hline 36 & 47 & 203 \\
\hline SUM & $\mathbf{2 8 6}$ & \multicolumn{2}{c}{} \\
\hline
\end{tabular}

The neologisms directly related to tourism describe new kinds of "isolated" breaks or holidays (e.g. coronabreak, corona holiday) or new forms of vacationing (gramping, workation, coronacation, safecation, schoolcation, drivecation, genervacation and the reactualisation of staycation). The latter shows the great productivity of the libfix "-cation", but this was also observed in the pre-Corona era. The libfix "-moon" (derived from honeymoon) is a similar case (e.g. solomoon). Neologisms deal with new leisure practices that emerged during the isolation period (coronactivity, covid parties, covideo party, videoparty, zoom party, covid walk, virtual happy hour, overdistancing) or with the enjoyment of various 
gastronomic offerings (locktail, locktail hours, quarantini, quarantining, COVI-latte). Different ways of doing business without direct physical contact between supplier and consumer (uberise, contactless, cashierless, corona shake). Most illustrative of the current situation in tourism are the expressions that aim at stagnation in the tourism sector (non-tourism, zero tourism) or those that emphasize the avoidance of non-essential travel (also unhyphenated version also appeared: nonessential). Alongside this, the idea of increased travel after it has become safer has appeared recently, encapsulated in the term revenge travel. The return of tourism is also referred to by the term tourist vouchers, which are issued by governments to boost tourism again. Various methods of safe travel became possible (Covid bubble, travel bubble, zoom tourism, health passport, immunity passport) and the dissemination of information reached the point of infodemic.

The indirect coronaneologisms are concerned with describing the situation of not being able to move freely, that is, to travel (\#stayhome, coronacave, self-isolating, self-quarantine, iso) and to engage (coronabusy, coronatime, isobaking, telecommuting), including through online and safer ways of meeting people (coronabrations, covideo, covideogames, elbow bump, elbump) and shopping (covidshop, cashierless). The pandemic period had a massive impact on people (anthropause, Coronapocalypse, coronacoaster, overzoomed), with negative effects (coronadodge, coronanoia coronaphobia) also expressed in security measures (safentry, cashierless, bubble, biosurveillance, sanitagging, security hygiene, cleanliness theatre). Coronaneologisms were also coined to describe the comparisons between preCorona, Corona and post-Corona eras (pre-corona, $B C, B C V$, postcorona) and to mention already the end of pandemics (covexit). The flood of new expressions was also observed (coronacoinages, coronaspeak).

\subsection{CONCLUSION}

The list of tourism-related coronaneologisms, directly and indirectly related to tourism, seems quite long, considering the brevity of the period in which the words were created. Almost one third of the extracted coronaneologisms $(28 \%)$ were related to tourism in one way or another, proving that tourism is a de facto buzz topic on its own. Some of the new lexis will remain and enter the English permanent vocabulary, but its frequency of use is expected to decrease once the topic COVID -19 is removed from discourse community's daily conversations. However, a greater proportion are expected to disappear with the virus, underlining the claim that languages reflect our social realities. In any case, the establishment of sections in dictionaries devoted to coronaneologisms underscores the claim that the COVID -19 influence has had a massive impact on the sociocultural aspects of our lives, as reflected in language lexis, morphological and phonological rapid changes. The observed coronaneologisms are in the neologistic phase of the development of the lexical cycle, which requires further future research, as neologisms are indeed particularly time-bound. Nevertheless, this work represents a fragment in the first steps of coronaneologism analysis of language for tourism purposes, which to our knowledge is the first scientific attempt to decipher the lexical changes with which the COVID -19 pandemics have affected this particular discourse. 


\section{REFERENCES}

Akut, K. B. 2020. Morphological Analysis of the Neologisms during the COVID-19 Pandemic. International Journal of English Language Studies. 2(3): 1-7.

Algeo, J. (ed.). 1991. Fifty Years Among the New Words: A Dictionary of Neologisms, 1994-1991. Cambridge: CUP.

Alyeksyeyeva, I. O., Chaiuk, T. A. \& Galitska, E. A. 2020. Coronaspeak as Key Coronaculture: Studying New Cultural Practices Through Neologisms. International Journal of English Linguistics. 10(6): 202-212.

Al-Salman, S. \& Haider, A. S. 2021. Covid 19 Trending Neologisms and Word Formation Processes in English. Russian Journal of Linguistics. 25(1): 24-42.

Al-Azzawi \& Ali-Haleem, A. 2021. "Do you Speak Corona?": Hastags and Neologisms Since COVID19 Pandemic Outbreak. International Journal of Linguistics, Literature ad Translation. 4(4): 113-123.

Anesa, P. 2018. Lexical Innovation in World Englishes: Cross fertilization and Evolving Paradigms. London, New York: Routlege.

Asif, M., Zhiyong, D., Iram, A. \& Nisar, M. 2020. Linguistic Analysis of Neologism Related to Coronavirus (COVID-19). Social Sciences \& Humanities Open. Available at SSRN: https://ssrn.com/abstract=3608585.

Barrs, K. 2015. Catachrestic and Non-Catachrestic English Loanwords in the Japanese Language. In Formato, F. \& Hardie, A. (eds.). Abstract Book of Corpus Linguistics, 372-374. Lancaster: UCREL

Bolotina, E. A. 2021. Covid-Neologisms in the English Speaking Media and the Means of Their Word Formation. Collection of Materials: XVII International Scientific and Practical Conference of Young Scientists. Novosibirsk, November 26 - 27, 2020. pg. 24-28.

Bharati, P. 2020. Covid 19 Neologisms in English. Saptagandaki Journal. 11: 122-135.

Cabré M. T. 1998. Terminology: Theory, Methods and Applications. Amsterdam, Philadelphia: John Benjamins Publishing.

Crystal, D. 2003. The Cambridge Encyclopedia of the English Language. Cambridge: Cambridge University Press.

Crystal, D. 2003. The Cambridge Encyclopedia of the English Language. Cambridge: Cambridge University Press.

Csak, E. 2011. The Translation of Neologisms in Special Terminology. Translation Journal. 5(3).

Fischer, R. 1998. Lexical Change in Present-Day English: A Corpus Based Study of the Motivation, Institutionalisation and Productivity of Creative Neologisms. Tübinger: Gnv.

Francl, M. 2011. Neolexia. Nature Chemistry. 3: 417-418.

Gössling, S., Scott, D. \& Hall, M. 2021. Pandemics, Tourism and Global Change: A Rapid Assessment of COVID-19. Journal of Sustainable Tourism. 29(1): 1-20.

Gladkova, A. 2015. Ethnosyntax. In: Sharifian, F. (ed.). The Routlege Handbook of Language and Culture. Abingdon: Routlege. 33-50. 
Gložančev, A. 2009. Analitična osvetlitev novejše slovenske leksike. In Gložančev, A., Jakopin, P., Michelizza, M., Uršič, L. \& Žele (eds.): Novejša slovenska leksika (v povezavi s spletnimi jezikovnimi viri), 9-35. A. Ljubljana: Založba ZRC, ZRC SAZU.

Grzega, J. 2021. From Corona Party to Coronapaniek: Cross-Linguistic Critique of Covid-related Contributions to Wiktionary. Language \& Internet. 19(2021).

Haddad Haddad, A. \& Montero-Martinez, S. 2020. COVID-19: A Metaphor-based Neologism and Its Translation into Arabic. JCOM. 19(5): 1-21.

Halliday, M.A.K. \& Yallop, C. 2007. Lexicology: A Short Introduction. London: Continuum.

Harley, H. 2006. English Words: A Linguistic Introduction. Oxford: Blackwell Publishing.

Jaworski, A. \& Pritchard, A. (ed.). 2005. Discourse, Communication and Tourism. Clevedon, Buffalo in Toronto: Channel View Publications.

Janseen, M. 2013. Lexical gaps. In Chapelle, C. A. The Encyclopaedia of Applied Linguistics. Blackwell Publishing. Available at: http://onlinelibrary.wiley.com/doi/10.1002/9781405198431.wbeal0693/full. (Accessed on 15.1. 2014).

Katermina, V.V. \& Lipiridi, S. C. 2020. Reflection on the Social and Psychological Consequences of the Coronavirus Pandemic in the new Vocabulary of Non-professional English Language Discourse. Advances in Social Science, Education and Humanities Research. Proceedings of the Research Technologies of Pandemic Impact (RTCOV 2020). Atlantis Press. Pg. 44-49.

Khalfan, M., Batool, H. \& Shehzad, W. 2020. Covid-19 Neologgisms and their Social Use: Analysis from the Perspective of Linguistic Relativism. Linguistics and Literature Review. 6(2): 117-129.

Kerreman, D. 2015. A Web of New Words. A Corpus-based Study of the Conventionalization Process of English Neologisms. Frankfurt: Peter Lang.

Kesckes, I. 2015. Language, Culture and Context. In: Sharifian, F. (ed.). The Routlege Handbook of Language and Culture. Abingdon: Routledge.

Lawson, R. 2020. The Conversation. Available at: theconversation.com. Accessed on: 1 June 2021.

Lehreh, A. 2003. Understanding Trendy Neologisms. Italian Journal of Linguistics. 15 (1): 271-384.

Lei, S., Yang, R. \& Huang, C. 2021. Emergent Neologisms: A Study of Emerging Meaning with Competing Forms Based on the First Six Months of COVID-19. Lingua. (2021).

Mahmudi-Dehaki, M., Chalak, A. \& Tabrizi, H. H. 2020. The COVID-19 Lingo: Societies' Responses in form of Developing Comprehensive Covidpedia of English vs. Persian Neologisms (Coroneologisms). The Journal of Englsih Language Pedagogy and Practice. 13(27): 26-52.

Muhvić-Dimanovski, V. 2005. Neologizmi. Problemi, teorije i primjene. Zagreb: Zavod za lingvistiku, Filozofska fakulteta Sveučilišta v Zagrebu.

Mweri, J. 2021. Corona Virus Disease (COVID-19) Effects on Language Use: An Analysis of Neoogisms. Linguistics and Literature Studies. 9(1): 36-48.

Newmark. P. 1995. A Textbook of Translation. New York: Prentice Hall.

Rets, I. 2016. Teaching Neologisms in English as a Foreign Language Classroom Procedia - Social and Behavioral Sciences. 232(2016): 813-820.

Rey, A. 1995. Essays on Teminology. Amsterdam: John Benjamins Publishing.

Roig-Marin, A. 2020. English-based Coroneologisms: A Short Survey of Our Covid-19 Related Vocabulary. English Today. 1-3. 
Samylicheva, N. \& Gazda, J. 2020. Derivative Neologisms as Sociocultural Dominants in the Russian and Czech Langauges of the Modern Period. SHS Web of Conferences 88 (2020), International Scientific Forum "Issues of Modern Linguistics and the Study of Foreign Languages in the Era of Artificial Intelligence (LLT Forum 2020).

Simeon, R. 1969. Enciklopedijski rječnik lingvističnih naziva. Zagreb: Matica hrvatska.

Stojičić, V. 2004. Sociolinguistic Stimuli to the Development of the English Lexicon - Language Contact and Social Need. Linguistics and Literature. 3(1): 29-36.

Toporišič, J. 2000. Slovenska slovnica. Maribor: Založba Obzorja.

UNWTO. 2021. Tourist Arrivals Down 87\% in January as UNWTO Calls for Stronger Coordination to Restart Tourism. Available at: https://www.unwto.org/news/tourist-arrivals-down-87-injanuary-2021-as-unwto-calls-for-stronger-coordination-to-restart-tourism. (Accessed on: 2 June 2021).

UNWTO, 2021. UNWTO World Tourism Barometer. 19(2). Pg. 1-32. Available at: https://www.eunwto.org/loi/wtobarometereng. (Accessed on: 2 June 2021).

Žele, A. 2010. Pomenotvorne zmožnosti z vidika /de/terminologizacije (v slovenščini). In Ledinek, N. \&, Žagar Karer, M. \& Humar, M. (eds.). Terminologija in sodobna terminografija, 125-139. Ljubljana: Založba ZRC, ZRC SAZU. 